\author{
Elżbieta KURZĘPA ${ }^{1}$ \\ Katarzyna KURZĘPA-DEDO
}

\title{
CONSEQUENCES OF THE LIQUIDATION OF THE BANK ENFORCEMENT TITLE AND SOCIAL EXPECTATIONS
}

\begin{abstract}
The subject of the article is an analysis of the regulation of the banking enforcement title in the provisions of Polish law, the reasons for its revocation by the Constitutional Tribunal in the judgment of 14.04.2015 and the use of new instruments by banks for the quick and effective recovery of claims from their clients. Considerations are conducted both in the context of the constitutional principle of equality and the principle of "equality of arms" between banks and their clients in court proceedings, as well as social expectations regarding the abolition of banking privileges. The article also analyzes the effects of the repeal on 07.11.2019 of the Article $485 \S 3$ of the Code of Civil Procedure which constitutes the basis for banks to obtain orders for payment in order for payment based on an excerpt from bank books signed by persons authorized to make statements regarding the property rights and obligations of the bank, which in practice constituted a kind of "new version" of the repealed banking enforcement title.
\end{abstract}

Keywords: enforcement banking privileges, banking enforcement title, order for payment, writ of payment order.

\section{INTRODUCTION}

The issuing of bank enforcement titles was one of the most important and at the same time the most controversial privilege that allowed banks to use the simplified procedure, as the debt recovery procedure from their clients was bypassed ${ }^{3}$. However, this put the client-debtor at a disadvantageous procedural situation, leading to an imbalance between him and the bank, which should be maintained as part of the civil law legal relationship between these two entities. For this reason, opponents of the b.e.t. - putting the need to protect the interests of bank customers first - pointed to the need to remove it from the provisions of the Banking Law (Janiak, 2003). Supporters of the b.e.t. argued that it allowed the bank as a so-called public trust institutions for quick and facilitated pursuit of their

${ }^{1}$ Elżbieta Kurzępa, PhD, Rzeszow University of Technology, Faculty of Management, Department of Law and Administration, ul. Akademicka 2, 35-084 Rzeszów; e-mail: e_kurzepa@prz.edu.pl (corresponding author). ORCID: 0000-0003-0032-8607.

2 Katarzyna Kurzępa-Dedo, PhD, College of Media and Social Communication, Chair of Political Sciences and Administration, University of Information Technology and Management in Rzeszów, ul. H. Sucharskiego 2, 35-255 Rzeszów; e-mail: kkurzepa@ wsiz.rzeszow.pl. ORCID: 0000-0002$-4823-1217$.

${ }^{3}$ Bank enforcement title (hereinafter: b.e.t.). 
claims in order to maintain, among others payment liquidity and ensure adequate protection of funds entrusted to it by depositors (see Kaszubowski, Tupaj-Cholewa, 2010; Fojcik-Mastalska, 2010; Janus, 2017).

Constitutional Tribunal several times (See: the judgment of the Constitutional Tribunal, 1995; the judgment of the Constitutional Tribunal, 2005; the order of the Constitutional Tribunal, 2005; see also: Kryński, 2007; Zapadka, Mikos-Sitek, 2009) analyzed the execution privilege under Art. 96-98 bank accountability (Act, 1997; hereinafter referred to as bank attorney). Among other things, in the judgment of 26 January 2005 (P 10/04, OTK-A 2005, No. 1, item 7) the Tribunal examined whether the right to issue bank enforcement titles is consistent with the constitution in the context of the right to court and the rule of law as well as protecting consumer rights. It considered then that the service by banks of the b.e.t. does not violate art. 45 item 1 in connection with art. 2 and art. 76 of the constitution. Moreover, the Constitutional Tribunal emphasized that the debtor before the uprising of b.e.t. may bring an action to establish the existence or non-existence of a legal relationship (Article 189 of the Code of Civil Procedure) (Act, 1964, hereinafter as the Code of Civil Procedure), while raising an objection of invalidity or ineffectiveness of the declaration submitted. However, after the enforcement clause has been granted, the debtor may defend his rights by: appealing to the court's decision to grant the enforcement clause (Civil Procedure Code Art.795), anti-enforcement action (Civil Procedure Code Art.840), an action for damages based on Art. 415 of the Civil Code in the event of damage caused to him as a result of instigating enforcement on the basis of an unlawfully issued title.

Despite such arguments of the Constitutional Tribunal and the statement that the privileged enforcement position of banks does not lead to a gross violation of consumers' interests, especially in the context of specific information obligations of banks when concluding contracts, the discussion on the need to remove the b.e.t. from the Polish legal order and more broadly equating the position of banks with the position of their clients.

At this point, it is worth mentioning the judgment of the Constitutional Tribunal of 15.03.2011 (Journal of Laws No. 72, item 388), in which the Constitutional Tribunal ruled that art. 95 paragraph 1 bank account in the wording given by the Act of June 26, 2009 amending the act on land and mortgage registers and some other acts (Act amending the act on books ..., 2009), in connection with art. $244 \S 1$ and art. 252 of the Act of 17.11.1964 Code of Civil Procedure (consolidated text, Journal of Laws of 2018, item 1360 as amended), in the part in which it gives legal effect to an official document in the bank's accounting books and excerpts from the books bank accounts in relation to the rights and obligations arising from banking activities in civil proceedings conducted against the consumer - is not in accordance with art. 2, art. 32 section 1 first sentence and art. 76 of the Constitution. In implementing the provisions of this judgment, the Act of 12 April 2013 amending the provisions of the Banking Law and the provisions of the Investment Funds Act (Act, 2013; for more see Kurzępa-Dedo, Kurzępa, 2016) lifted one of the significant banking privileges classified as so-called enforcement privileges of banks (Kaszubowski, Tupaj-Cholewa, 2010), namely deprived the power of official documents of accounting books and excerpts from the bank's accounting books in civil proceedings. The above amendments to the Banking Law came into force on July 20, 2013 and were intended by the legislator to ensure "equality of arms" of the bank on the one hand and clients on the other as part of civil proceedings in accordance with the principle that no one could be considered a credible witness in their own case (nullus idoneus testis in re sua intelligitur). During the legislative work on the Act of 12/04/2013, a postulate was made to eliminate, in 
addition to depriving of official power bank documents and securitization fund documents, at the same time eliminate another, functionally associated banking privilege - the bank enforcement title. At the time, this idea did not gain the approval of the majority in the Sejm and was rejected ${ }^{4}$.

The verdict of April 14, 2015 (P 45/12, OTK-A 2015/4/46), in which the Constitutional Tribunal stated that art. 96 section 1 and art. 97 paragraph 1 of the Act of 29 August 1997 Banking Law are incompatible with art. 32 section 1 of the Constitution and the principle of equality expressed in it. As a consequence of such a resolution, the above-mentioned provisions governing the bank enforcement title and the rules for issuing it lost its validity as of August 1, 2016.

The purpose of the article is to present the regulations of the b.e.t. in Polish law and a discussion of the effects of its removal from the Banking Law for banks as well as their clients, especially from the point of view of the ratio legis of such a solution declared by the legislator and social expectations in this respect. The hypothesis that the removal of the bank enforcement title will, as a rule, equalize the trial situation of bank customers will only be verified. In practice, banks to a much greater extent than until the date of the expiry of the binding force of the provisions of Art. 96-98 bank accountability used to pursue their claims, simplified proceedings, first of all writ proceedings, whose scope of protection of the debtor's rights is similar to the model for obtaining an enforcement clause for the b.e.t.

\section{THE HISTORY OF THE BANK ENFORCEMENT TITLE IN POLISH LAW}

The history of the bank enforcement title in Polish legislation dates back to the interwar period, but then its subject and the scope were narrower compared to the institution's model resulting from post-war regulations. Pursuant to art. 87 of the Regulation of the President of the Republic of Poland of January 20, 1924 regarding the establishment of the statute for the issuing bank, the books of the Bank of Poland and other entries included in the bank's accounting and extracts thereof authenticated by the bank, had the probative value of public documents, and documents stating obligations with the bank's statement that the claim based on them is due and legally mature for enforcement, obtained the status of executory titles (consolidated text Journal of Laws of 1939, No. 46, item 296). An enforcement clause for these titles was granted by the competent town court according to the provisions of the then applicable Code of Civil Procedure (Act, 1930, art. 533 et seq.)

The enforcement privilege in question could also be used by banks with public funds allocated for the implementation of tasks commissioned by the state, inter alia in the scope of supporting certain entities. The aforementioned aid was mainly related to the removal of the effects of the great economic crisis and concerned only some of the real estate pledged as collateral for certain types of debt. For example, the Act of March 24, 1933. on facilities for credit institutions, granting debtors relief in respect of agricultural claims provided for the possibility for the Acceptance Bank to issue (for more on the activities of the Acceptance Bank see Morawski, 1996) enforcement titles without the need to obtain court enforcement clauses for them Act, 1933, art. 11 paragraph 1). On the other hand, in the regulation of the President of the Republic of Poland of October 21, 1932 on the execution of real estate enforcement by the State Agricultural Bank (Journal of Laws No. 91, item 769), the

\footnotetext{
${ }^{4}$ See, among others, the statement by J. Żyżyński, a Law and Justice deputy at the meeting of the Sejm Public Finance Committee on April 17, 2013 (http://orka.sejm.gov.pl/Zapisy7.nsf/ wgskrnr/FPB-161; more broadly: Kurzępa, Kurzępa-Dedo, 2016)
} 
simplified claims procedure was allowed only for the purpose of realizing the debt enforced in the first place by the Państwowy Bank Rolny (National Agricultural Bank) due to a loan granted in mortgage bonds or bonds of the bank, and State Treasury receivables belonging to the Agricultural Reform Fund for land sold for sale or granted for consideration (art. 2 sent. 1).

Banks after World War II gained much broader enforcement privileges, which was associated primarily with their special status as part of the command and distribution economy, including on the financing of the economic sectors assigned to them. For instance, in November 1949, the Municipal Bank financed local government, and in 1950 the Agricultural Bank responsible for credited agriculture and forestry (for more information: Białas, Mazur, 2016). In the wake of the role of the banking apparatus in this way, in creating the socialist economy, legislation has begun to equip banks with imperious forms of action in relation to the entities served (see Sura, 2016).

In the decree of 15 January 1945 on the National Bank of Poland (Journal of Laws No. 4, item 14), in Art. 40 the instruction was issued, according to which documents confirming the liabilities with the bank's statement that the claim based on them is enforceable and legally mature for enforcement, have the force of enforceable titles. In the bank reform decree of October 25, 1948 (Journal of Laws No. 52, item 412) all banks were authorized to use bank enforcement titles. Moreover, from the date of entry into force of the said decree, they did not have to be granted judicial enforcement clauses, and the execution itself was carried out at the bank's choice either in accordance with the provisions of the Code of Civil Procedure or in administrative enforcement. The institution of the banking enforcement title, and in principle the banking enforcement title in the subject and subject scope described was maintained in the provisions of the banking law: of April 13, 1960, of June 12, 1975, of February 26, 1982 and of 31 January 1989 (See Act, 1960, art. 21, section 2; Act, 1975, art. 16, section 2; Act, 1982, art. 94, section 2; Act, 1989, art. 53, paragraph 2).

In view of such a strong enforcement position of banks, the legislator, in order to strengthen the situation of the debtor, granted him in banking law - starting from the Act of 13 April 1960 - the possibility of bringing an action to discontinue all or part of the enforcement carried out by the bank on the basis of a bank enforcement title both in court and in administrative proceedings. The debtor could indicate in the grounds of his action: the absence of the enforced claim, its existence in an amount less than that pursued by the bank, or submit a counterclaim suitable for offsetting with a bank claim covered by the bank enforcement title. The claim could be secured, at the plaintiff's request, by suspending the enforcement proceedings (Banking Law of $\backslash 1989$, art. 53, section 4).

Bank enforcement titles were used by banks to pursue claims arising from their banking activities, the so-called sensu stricto (Articles 4 and 11 (1) of the then Banking Law) (Sikorski, 1997). However, they were not issued for any claims arising from banking activities classified as so-called sense largo (Judgment of the Supreme Court, 1995). In addition, it has been emphasized in the literature that a banking enforceable title can only issue a bank against its personal debtor (borrower, guarantor, guarantor), and not a material debtor (e.g. due to his establishing a mortgage or pledge) (Szpunar, 1995). In connection with the issuing on January 3, 1996 by the President of the Constitutional Tribunal, an announcement on the loss of binding force of Art. 53 section 2 of the Banking Law Act, it was not possible to issue a banking enforceable title against the debtor of a claim acquired 
by transfer. The above rules for issuing banking writings were in force until January 1 , 1998, which is the entry into force of the Banking Act of August 29, 1997.

\section{ISSUING OF BANK ENFORCEMENT TITLES PURSUANT TO ART. 96-98 OF THE BANKING LAW}

In accordance with art. 96 of the Banking Law of 29.08.1997, banks could issue bank enforcement titles, being a type of enforcement title, referred to in Art. $777 \S 1$ item 3 of the Code of Civil Procedure (CCP) (Act, 1964). They were based on the books of banks or other documents related to banking activities, of which - listed in art. 96 section 2 right bank - data had to be found in b.e.t. The lack of any of these elements resulted in the court rejecting the application for an enforcement clause b.e.t.

It should be noted that the bank enforcement title could only be issued by a bank, including a mortgage - to the extent that it was authorized to perform specific banking activities - and cooperative savings and credit unions, which issued the so-called executory titles (no longer in force in Article 29a) (Act on cooperative ..., 2009). The central bank did not have such competences (Act on cooperative ..., 2009; Kryński, 2000). A bank enforcement order may be issued only in respect of a claim arising from a banking act (Article 5 of the Banking Act) or used to secure a debt arising from such an act. Banking activities in connection with which the bank could issue a bank enforcement order were those listed in art. 5 paragraph 1 and 2 of the Banking Law (Resolution of the Supreme Court, 1999). The issue of the designation of a banking activity, on the basis of which the b.e.t. was issued, was subjected to the analysis of the Supreme Court (Gronkiewicz-Waltz, 2013), which in a resolution of 19 March 2010 found that the banking operation was established in the b.e.t. should be indicated in a way enabling its identification as a banking activity within the meaning of art. 5 right bank (III CZP 6/10, OSNC 2010, No. 9, item 120). It should also be emphasized that the bank enforcement title could not relate to the activities referred to in art. 6 of the Banking Law.

B.e.t. as a rule, facilitated the banks' recovery of overdue receivables from customers. A condition for initiating and carrying out enforcement by banks on the basis of b.e.t. was to grant the bank enforcement title, an enforcement clause only against a person who directly performed banking activities with the bank or was the debtor of the bank for securing the bank's receivables arising from banking operations, and also made a written declaration of submission to enforcement, and the claim under the title resulted directly from this banking activities (Marszałkowska-Krześ [ed.], 2017). It should also be noted that it was permissible to issue a bank enforcement order against a guarantor, also against a bill of exchange guarantor (Piasecki, 2015).

It should also be noted that pursuant to art. 97 of the Banking Law the b.e.t. could be provided with an enforcement clause only when the person against whom he was issued made a written statement (ad probationem) (Sikorski, 2019) on submission to enforcement and when the claim covered by the title resulted directly from this banking activity or its security. The statement specified the amount of debt (principal and incidental benefits e.g. interest, including for delay, costs, etc.), to which the bank may issue a bank enforcement order, and the date by which the bank may apply for an enforcement clause. Both elements of the statement indicated the maximum ratios because the bank could not issue the b.e.t. for an amount higher than stated in the statement, even if the debtor's actual debt was higher. As for the form of the declaration of submission to enforcement, it required a written form. 
It could be included in the contract from which the claim arose, or it could be an independent document.

The clause proceeding regarding the granting of the bank enforcement title the enforcement clause was conducted according to art. $781^{1}$ and then according to C.C.P. The repealed art. 97 paragraph 3 of the Banking Law like $781^{1}$ C.C.P. provided for a 3-day, instructional deadline for posting b.e.t. an enforcement clause from the date of submission of the application in this regard. Meeting this deadline was not a condition for the effectiveness of the enforcement clause (Piasecki, 2015). There is no doubt, however, that the time taken by the bank to obtain the writ of execution which constituted the basis for initiating enforcement proceedings was definitely shorter than in the case of payment being claimed by other creditor entities.

In initiating the clause proceedings, the bank was obliged to present, in addition to the bank enforcement title itself, also documents that justified its issuing. In accordance with art. 97 of the Banking Law they were: the debtor's declaration of submission to enforcement, documents showing the legal succession of the debtor) (Sikorski, 2019). As argued in the case-law, the failure to submit these documents could not be sanctioned pursuant to Article 130 of the Code of Civil Procedure, as they constituted the substantive basis of the application (Resolution of the Supreme Court, 2001).

As mentioned before, it was only giving the b.e.t. the enforcement clause made it the enforceable title constituting the basis for enforcement. It is worth noting that the clause procedure was not costly, comparing it with the payment procedure, in which the creditor must prove the existence and amount of the claim being pursued. In accordance with art. 77 section 1 point 3 of the Act of July 28, 2005 on court costs in civil matters, the fee that was charged in the clause proceedings was an office fee of PLN 6 for each started page of the issued document (Journal of Laws of 2019, item 785; amounts in the validity of the b.e.t. provisions). Currently, the fee is PLN 20. In a situation where the creditor wants the b.e.t to have the enforcement clause, he would be represented in the clause proceedings by a lawyer or a legal advisor, which in the case of banks usually took place, then he could demand from the debtor against whom the bank enforcement order was issued, the reimbursement of the costs of legal representation. The minimum rate on providing the enforcement order with an enforcement clause, in accordance with $\S 8$ par. 1 point 14 of the Regulation of the Minister of Justice of October 22, 2015 (Journal of Laws of 2015, item 1800 as amended) amounted to PLN 120 (amounts during the validity of the provisions on the b.e.t.). Therefore, it should be noted that the initiation of the clause proceedings was beneficial in terms of the costs incurred not only for the creditor (these costs came down to the office fee in the above-mentioned amount), but also for the debtor. It is true that he was not able to participate in such proceedings due to the fact that it was conducted in closed mode and on the decision on the provision of the enforcement order with an enforcement clause, he was not entitled to complain, but the possible costs of the clause proceedings, which the creditor could recover from the debtor, they were certainly lower than in the case of standard payment proceedings (also in a prescriptive and admonition procedure), in which the fee for a lawsuit constituted in principle $5 \%$ of the value of the subject of the dispute, and the minimum rate in the scope of lawyers' fees also depended on the amount claimed in the lawsuit. Considering the overdue amounts that banks usually demand from their clients, it should be estimated that the costs of a possible legal representation should be estimated at amounts several or several dozen times higher than in the case of clause proceedings. The ruling on the costs related to the procedure for granting an enforcement clause, contained 
in the content of this clause, constituted an enforceable title entitling them to download them (Resolution of the Supreme Court, 1974).

The bank enforcement title was provided with an enforcement clause in closed session by way of a decision on which a complaint could be lodged. According to art. 795 paragraph $2 \mathrm{CCP}$ the deadline for lodging a complaint ran for the creditor from the date of issuing him the writ of execution or notifying him of the creation of the writ of execution in the ICT system or from the day of announcing the refusal, and when the announcement was not from the day of delivery of that order. For the debtor, this period ran from the date of delivery of the notification of the initiation of enforcement. It is clear from the above provision that the debtor's ability to question the legitimacy of giving b.e.t. the enforcement clause, unlike the creditor, i.e. the bank, could only take place after the initiation of enforcement proceedings and did not stop the proceedings in any way (see Janas, 2013) ${ }^{5}$. It is argued in the doctrine that, in a complaint against a decision granting an enforcement clause, substantive objections as to the existence and scope of the debtor's obligations or creditor's rights cannot be raised. Thus, the debtor's substantive defense was only made possible by an anti-enforcement action (Zedler, 1995; Pietrzkowski, 2009). By way of complaint, formal defects committed by the court in the course of proceedings for granting an enforcement clause should be combated (Resolution of the Supreme Court, 1985; Zieliński [ed.], 2012).

While the clause proceedings are not very costly proceedings from the point of view of both the creditor and the debtor, it prevented the debtor of the bank from undertaking substantive questioning issued by the bank b.e.t.

Valid provision of the b.e.t enforcement clause, in turn, made it possible to initiate enforcement proceedings which, without submitting the enforceable title, could not be initiated. It constituted the last stage in the procedure of the bank's recovery of overdue receivables, under which the legal norms specified in the enforceable title were enforced (Zieliński [ed.], 2012), but on the other hand it created the possibility for the debtor to change the enforceable title, i.e. in the course of an anticompetitive action. It is worth adding that anti-enforcement actions are subject to a court fee of $5 \%$ of the value of the subject matter of the dispute, which in an action for deprivation of enforceability is the challenged amount established by an enforceable title.

Liquidation of the b.e.t. occurred on the basis of the provisions of the Act of 25 September 2015 amending the Banking Act and some other acts (Journal of Laws of 2015, item 1854), which is the implementation of the Constitutional Tribunal's judgment of April 14, 2015 (reference number P 45/12) recognizing the contradiction of bank enforcement titles to Art. 32 section 1 of the Constitution.

In the justification of the judgment, the Constitutional Tribunal decided that the possibility of using the b.e.t. in the event of a contractual relationship between customers and banks, which by its very nature is characterized by the equivalence of parties, places banks (private business entities) in a privileged position. This, in turn, contradicts the essence of a private law relationship, whose characteristic feature is, among others parity in the scope of the possibility of defending one's rights (Sura, 2016).

In addition, in the opinion of the Constitutional Tribunal, the bank is therefore a judge in its own case (iudex in causa sua) and de facto the subject of justice, which, according to

\footnotetext{
5 The author analyzes the procedure for granting an enforcement clause b.e.t. in the context of
} exercising the right to court. 
art. 175 of the Constitution are exercised exclusively by the courts the b.e.t. also violates the principle of equality in relations between banks as creditors and other entities that are creditors that do not have such enforcement privileges. The institution of the b.e.t. in the end, it violates the principle of equality in relations between bank debtors and debtors of other entities (For different information see, i.a., Janus, 2017).

Pursuant to the abovementioned CT judgment, the provisions of the Banking Law Act regarding banking enforcement titles were to expire on August 1, 2016, unless the legislator decides to eliminate unconstitutional provisions from legal circulation earlier. The bank enforcement title was completely eliminated from the legal system earlier. The Act of 25 September 2015 repealing the provisions on the b.e.t. entered into force on 27 November 2015, repealing Art. 96-98 bank accountability The legislator justified the reduction of vacatio legis, among others by the fact that "after the Constitutional Tribunal's judgment, there will be an increased issuance by BTE banks in all possible matters subject to recovery" (from the justification to the Act of 25 September 2015 amending the Banking Law Act and some other acts). However, according to art. 11 paragraph 1 of the aforementioned Act, proceedings on granting an enforcement clause to the bank enforcement title initiated and not completed before its entry into force were subject to discontinuation. If, however, before the date of entry into force of this Act, a decision was issued regarding the granting of an enforcement clause to the bank enforcement title, further proceedings regarding the granting of the enforcement clause were conducted in accordance with the provisions on the b.e.t. (Article $11(2)$ )

\section{BANKS CLAIMS AFTER THE REPEAL OF BANK ENFORCEMENT TITLES}

The repeal of the bank enforcement order laws put banks in a difficult position. They lost the tool for automatic enforcement of overdue receivables, their position as creditor was weakened and finally they were forced to use other procedures for enforcing overdue receivables from even concluded loan agreements, which would guarantee optimal protection of banks' interests. Therefore, the possibility of making the conclusion of the contract between the bank and the debtor dependent on the debtor's submission to enforcement by means of a notarial deed (Article $777 \S 1$ item 5 of the Code of Civil Procedure), as well as pursuing claims under the order for payment procedure (and on the basis of non-binding on November 7, 2019, Article $485 \S 3$ of the Code of Civil Procedure $)^{6}$.

Anyway, for such a possible consequence of the liquidation of b.e.t. pointed out the vice president of the Polish Bank Association - Jerzy Bańka, saying that "this regulatory change hits customers - paradoxically not those who take out a loan knowing immediately that they do not intend to repay them, but in those who do not repay loans for various reasons random. The main instrument that will serve to accelerate and ensure the efficiency of bank recovery is the practice of borrowers issuing blank promissory notes for low-value loans. In the case of mortgage loans and corporate loans, banks will use declarations of submission to enforcement by means of a notarial deed. This will result in additional costs (https://www.pb.pl/zbp-ostrzega-przed-Skutkom-likwidacji-bankowego-tytuluegzekucczego-790592).

\footnotetext{
${ }^{6}$ Article $485 \S 3$ of the Code of Civil Procedure was repealed by art. 1 point 176 lit. c of the Act of 4 July 2019 amending the Act - Code of Civil Procedure and certain other acts (Journal of Laws of 2019, item 1469) on November 7, 2019.
} 
There is no doubt that the procedural situation of the bank and the debtor in the event of submission of the latter enforcement by a notarial deed is in principle similar to the case of the b.e.t. but with the difference that the bank's clients will be obliged to bear the costs of preparing such a notarial deed. After the court grants an enforcement clause, a notarial deed in which the bank's debtor surrendered to enforcement becomes an enforceable title and the basis for initiating enforcement proceedings.

Banks more often used the option of initiating an order for payment procedure pursuant to art. $485 \S 3$ of the Code of Civil Procedure, repealed on November 7, 2019. The increase in the number of such proceedings was, of course, caused by the repeal of the b.e.t. and the need to use the fastest possible solutions for redress from bank customers. Pursuant to art. $485 \S 3$ of the Code of Civil Procedure the court issued an order for payment, if the bank sought claims based on an excerpt from the bank books signed by persons authorized to make statements regarding the property rights and obligations of the bank and the bank's seal, and proof of delivery to the debtor of a written request for payment. The increase in interest of banks in this form of debt collection, which is unfavorable from the point of view of bank customers' interests, was pointed out by the Ombudsman in his letter to the President of Polish Banks, while raising the lack of justification in further abolishing the privilege of bank claims (see the letter of Ombudsman Adam Bodnar to Krzysztof Pietraszkiewicz, President of the Polish Bank Association).

It should be noted that in accordance with art. 95 paragraph 1 of the Banking Law, bank accounts and statements based on them and other statements signed by persons authorized to make statements regarding the property rights and obligations of banks and bearing the bank's seal, as well as receipts of receivables prepared in this way have the legal force of official documents with regard to the rights and obligations arising from banking activities and collateral established for the bank and may constitute the basis for making entries in the land and mortgage registers. In turn, in accordance with paragraph 1a of the aforementioned Act, the legal force of official documents referred to in par. 1 shall not apply to documents listed in this provision in civil proceedings. For this reason, the Ombudsman also postulated that the provision of art. Art. $485 \S 3$ of the Code of Civil Procedure.

The bank's initiation of the order for payment procedure (most often resulting from the bank's client's failure to perform a credit agreement) should start with a judicial summons for payment. Such a request includes, in particular, an indication of the basis for the claim (in this case, a specific loan agreement), presentation and documentation of the circumstances of the debtor's delay, the amount of the main benefit and the incidental benefit, and an indication of the time limit for meeting the claim.

The abovementioned tender procedure is standard in all such legal disputes, especially taking into account the amendment to the provisions of the Code of Civil Procedure as regards strengthening the principle of amicable dispute resolution (Act on the amendment of certain acts in connection..., 2015). It should be noted that pursuant to art. $187 \S 1$ item 3 of the Code of Civil Procedure a claim to court should include information as to whether the parties have attempted mediation or other out-of-court resolution of the dispute, and if such attempts have not been made, an explanation of the reasons for not taking it.

If the debtor fails to perform the payment due to the bank despite the superstitious request for payment, it becomes necessary to initiate court proceedings, i.e. the creditorbank submits a claim for payment, usually under the order for payment procedure. The application should comply with the general requirements specified in art. 187 of the Code of Civil Procedure Until November 7, 2019, it also included an excerpt from the bank books 
attached to it containing the elements listed enumerated in art. $485 \S 3$ of the Code of Civil Procedure Such an extract constituted evidence of the defendant's delay in payment and determined the amount of benefit due. In addition, the plaintiff was obliged to pay a court fee on the claim, which in the case of proceedings for property rights (and this category of cases is undoubtedly the case for payment) is determined according to the value of the subject of dispute or the value of the subject of the appeal, and at the value of the subject of the dispute or the value of the subject of appeals over PLN 20,000, a relative fee of 5\% of this value is collected from the letter, but no more than PLN 200,000 (Act, 2005, art. 13). On the other hand, a fourth part of the fee is collected from an action in an order for payment, while three quarters of the fee is collected from a defendant in the event of an objection to a payment order issued in an order for payment (Article 19, paragraphs 2 and 4), and the fee cannot amount less than PLN 30 (Article 20, paragraph 1). In the event of an order for payment being issued in the order for payment procedure, it was served along with the lawsuit of the defendant, who within two weeks from the date of delivery could file charges against the order for payment (non-binding Article $491 \S 1$ of the Code of Civil Procedure). The essence of the order for payment issued under the order for payment procedure was that at the time of issue it was a title of security, enforceable without giving it an enforcement clause (Article $492 \S 1$ of the Code of Civil Procedure). This enforcement takes place by way of judicial enforcement or other means. In the first case, the provisions on enforcement proceedings apply, respectively, to the provision of security, while in the second case - provisions regarding this method (Civil Procedure Code Art.743). Nonenforcement of the order for payment as a security may consist in the debtor depositing the adjudicated amount with interest at the creditor's request on the deposit account of the Minister of Finance. The same applies to the submission to the court deposit of an amount equal to the value of the subject of the dispute, if the order obliges to release replacement items (Marciniak, Piasecki [ed.], 2016). Submission of charges by the defendant within a statutory period of 14 days resulted in the case being referred to a hearing, and the court then examined it either on the basis of general provisions or possibly in a simplified procedure. It should be noted that the lodging of the charges did not cause the payment order to lose its force. Only after the evidentiary proceedings were completed, in the judgment issued, the order for payment, in whole or in part, was the court upholding or repealing it and ruling on demanding the claim, or by order repealing the order for payment and rejecting the lawsuit or discontinuing the proceedings (non-binding Article 496 of the Code of Civil Procedure).

In the literature on the subject, they were raised in 2017 after the repeal of the b.e.t. suggestions that in the event of depriving the banking books of the power of bank documents, Art. $485 \S 3$ of the Code of Civil Procedure he lost his raison d'être and therefore it must be set aside (Jasiecki, 2017). It was emphasized that further functioning in the legal market of the possibility of obtaining an order for payment on the basis of an excerpt from bank books unjustifiably privileges the claimant who obtains the enforcement order on the basis of a private document issued by him. There is no doubt that the basis of the claim submitted under the repealed art. $485 \S 3$ of the Code of Civil Procedure only on excerpts from bank books, it generally abolished the need to prove the existence of a claim on the basis of other documents, e.g. a contract concluded with the defendant, its termination or a request for payment. In principle, the issuing of an order for payment by the court in this mode was possible after the presentation of a private document, without the bank having to prove the basis of the claim, which unreasonably led to privileged banks. A similar position 
regarding the legitimacy of the regulation specified under Art. $485 \S 3$ of the Code of Civil Procedure was taken by the Ombudsman, who in his letter of 27 January 2017 addressed to the Minister of Justice indicated that after the judgment of the Constitutional Tribunal of 14 April 2015, which questioned the constitutionality of the provisions constituting the basis for issuing bank enforcement titles, art. $485 \S 3$ of the Code of Civil Procedure it has become an instrument enabling banks to quickly bring lawsuits based on excerpts from bank books that can be heard by a court in order proceedings?

As for the change that followed the amendment to art. 95 Banking Law, it should be noted that, although it theoretically led to the equalization of the procedural situation of banks and its debtors, it was still possible for the creditor bank to obtain a court decision regarding the claim being pursued in a faster order procedure, in the event that the creditor bank had no document with the status of an official document but a private document. Numerous criticisms of art. $485 \S 3$ of the Code of Civil Procedure led to action to repeal it. A government bill was amended to amend the Code of Civil Procedure Act and certain other acts of November 27, 2017, which provided, inter alia, repeal of art. $485 \S 3$ of the Code of Civil Procedure (Https://legislacja.rcl.gov.pl/docs//2/12305652/ 12474240/12474241/). The proposed change was positively opinioned by the Legislative Council, which in its opinion of February 8, 2018 argued that "the proposal to eliminate the possibility of issuing an order for a bank claiming claims based on banking books deserves acceptance because it eliminates the privilege of banks over others creditors that may be qualified as contrary to art. 32 of the Constitution. It should be recalled that in the judgment of 14 April 2015 the Constitutional Tribunal recognized that art. 96 section 1 and art. 97 paragraph 1 bank account not in accordance with art. 32 of the Constitution. The arguments cited in this judgment are also valid regarding the bank privilege provided for in art. 485 and therefore the proposal to repeal Art. $485 \S 3$ "(https://radalegislacyjna.gov.pl).

In turn, the opinion prepared by prof. Andrzej Jakubecki, commissioned by the Center for Research, Studies and Legislation of the National Council of Legal Advisers on a draft act amending the Act - Code of Civil Procedure and some other acts (draft of November 27, 2017) of February 26, 2018, was different from the Council Legislative position regarding the repeal of Art. $485 \S 3$ of the Code of Civil Procedure. In this opinion, it was stated that the repeal of the provision which recognized the existence of an excerpt from bank books as the basis for issuing an order for payment in order proceedings (Article $485 \S 3$ of the Code of Civil Procedure) would cause the costs of the process of awarding a benefit to the bank to increase dramatically. Professor A. Jakubecki argued this view as follows: "I am not enthusiastic about this regulation, but with its repeal there is a potential risk that these costs will be passed on to the bank's contractors. A lost trial will result in the defendant being ordered to pay the costs and they will be higher than they would be in the order

\footnotetext{
7 According to the position of the Ombudsman, "the Ombudsman doubted the constitutionality of the regulations of art. $485 \S 3$ of the Code of Civil Procedure and unjustified differentiation of the procedural situation of a professional entity, which is a bank, in relation to the defendant consumer by granting the possibility of pursuing bank debts in order proceedings. In the Ombudsman's view, the preference for bank claims in writ proceedings leads to an imbalance in the process to the detriment of the weaker party, i.e. the defendant consumer. Meanwhile, in the current law, there are no grounds to maintain special rights with respect to banks in civil proceedings "((http://www.spprawy-generalne.brpo.gov.pl/yszneoly.php?pismo=957722\&sygnatura= V.510.5.2017).
} 
proceedings. In addition, banks will compensate for the risk related to pursuing claims against counterparties by increasing the amount of fees for their activities. This change will have adverse consequences, unless the banks modify their policy and in any case require the debtor to issue a promissory note or notarial submission to enforcement "(http://obsil.pl/wp-content/uploads/2018/05/Opinia-z-26-February-2018-R-to-designMS-KPC.pdf).

Taking the above position into account, it should be noted that the collateral for the performance of the loan agreement by the bank issuing a promissory note (usually in a blank form) is also associated with court order proceedings (Article $485 \S 2$ of the Code of Civil Procedure). The legal nature of the bill of exchange makes this way of securing the debt relationship a relatively risky tool. In addition, it should be noted that pursuant to art. 492 $\S 3$ of the Code of Civil Procedure the payment order issued on the basis of a bill of exchange, warrant, reverse or check becomes immediately enforceable after the time limit for settling the claim has expired. In the event of an objection, the court may, at the defendant's request, suspend execution of the order. This is undoubtedly a more disadvantageous solution for the bank's debtor than the order-making procedure in which the payment order is issued on the basis of an excerpt from bank books. In the case of a promissory note, immediate enforceability of the order for payment results from the force of law. Immediate enforceability means that the order for payment is fit for enforcement by way of judicial enforcement, regardless of its validity.

The aforementioned Act of 4 July 2019 amending the Code of Civil Procedure and some other acts of Art. $485 \S 3$ of the Code of Civil Procedure was repealed. In support of eliminating art. $485 \S 3$ of the Code of Civil Procedure it was raised inter alia that:

"In the current legal status, among the evidence that may constitute the basis for issuing an order for payment, an order for payment in the order proceedings still includes an extract from the bank books signed by persons authorized to make statements regarding the property rights and obligations of the bank and stamped with the bank's seal. In this way, the bank's right to obtain an enforceable title on the basis of its own private document is maintained. A similar situation with regard to the banking enforcement title was declared unconstitutional by the Constitutional Tribunal in the judgment of April 14, 2015 in case $\mathrm{P} 45 / 12$. Acknowledging the validity of the argumentation which gave rise to this decision and which mutatis mutandis also applies to the privilege of a banking document, this exceptional right should be abolished by repealing Art. $485 \S 3$ " (Justification to the draft act of 4 July 2019).

\section{CONCLUSIONS}

There is no doubt that the Constitutional Tribunal's judgment of September 25, 2015 has satisfied the public's expectations regarding the liquidation of bank enforcement privileges. However, despite the repeal of the b.e.t. it has formally deprived the creditor banks of an instrument that significantly simplifies the pursuit of claims from clients, and is in conflict with the principle of "equality of arms" in the dispute between the parties to the obligation relationship, but this did not lead to a real improvement in the procedural situation of the debtors themselves. Banks use other, normatively specified instruments, which - as noted in the above considerations - are relatively similar in terms of their structure to a banking enforcement title (e.g. a declaration of submission to enforcement in a notarial deed) or involve more serious bank debtors consequences, in particular in the financial sphere 
(pursuing claims under the order for payment procedure, in particular from a promissory note $)^{8}$.

Considering the opinion of bank representatives, it should be stated that the liquidation of the bank enforcement title did not significantly affect the effectiveness of pursuing claims from bank debtors by November 7, 2019, i.e. repealing Art. $485 \S 3$ of the Code of Civil Procedure constituting the basis for obtaining payment orders by banks. Moreover, there was no significant increase in the cost of loans, nor did the interest of clients of this type of contracts in banks decrease. Therefore, opinions are justified that the total liquidation of the b.e.t. it may have been carried out too hastily. In the literature, there were proposals to introduce "improvements" to this enforcement instrument by, among others the obligation to serve the decisions granting an enforcement clause b.t.e. and the debtor's ability to appeal against it within seven days (See more: Janus, 2017).

Disturbing, from the point of view of procedural equality of the parties, was the abuse by banks as a substitute for the b.e.t. payment orders obtained under the repealed art. $485 \S$ 3 of the Code of Civil Procedure, which was indicated by, among others Ombudsman. In this context, it can be forecast that after repealing on November 7, 2019, Art. $485 \S 3$ of the Code of Civil Procedure perhaps, apart from payment orders "in the ordinary manner", bills of exchange will become the main form of securing the interests of banks, which, due to the abstract nature of the bill of exchange obligation, will definitely have a negative impact on the situation of bank debtors.

\section{REFERENCES}

Bączyk M., Mojak, J., Niezbecka, E. (2000), Kontrowersje wokót bankowego tytułu egzekucyjnego. „Monitor Prawniczy” nr 4, Warszawa: C.H. Beck.

Białas, M., Mazur, Z. (2013), Bankowość wczoraj i dziś. Warszawa: Wyd. Difin.

Bieżuński, P. (2018). W kwestii wznowienia postepowania o nadanie b.t.e. klauzuli wykonalności. „Monitor Prawa Bankowego” nr 5.

Dekret z dnia 15 stycznia 1945 r. o Narodowym Banku Polskim (Dz.U. nr 4, poz. 14).

Dekret z dnia 25 października 1948 r. o reformie bankowej (Dz.U. nr 52, poz. 412).

Fojcik-Mastalska, E. (2010) [w:] Fojcik-Mastalska, E., red., Prawo bankowe. Wrocław: Wyd. Uniwersytetu Wrocławskiego.

Grajewski, A. (2016). Bankowego tytułu egzekucyjnego życie po życiu. „Palestra”, nr 7-8.

Gronkiewicz-Waltz, H. (2013). Prawo bankowe. Komentarz. Wyd. 1. Warszawa: Wyd. C.H. Beck, System Informacji Prawnej „Legalis”.

\footnotetext{
8 The cost of issuing a promissory note as security for claims under a loan agreement is not higher than the cost of issuing a bank enforcement order. These costs may possibly increase if the bank's client submits a declaration of submission to enforcement in a notarial deed (Article $777 \S 1$ item 5 of the Code of Civil Procedure). The notary tax in this case depends on the amount covered by such a declaration (e.g. in the case of an amount between PLN 30,000 and PLN 60,000, it will be a maximum amount of PLN $710+1 \%$ from the surplus above PLN 30,000). It should be remembered, however, that this is the maximum fee, rarely required by notaries. In addition, as representatives of banks point out, contrary to earlier predictions, the declaration of submission to enforcement by means of a notarial deed has not yet become a common tool for securing the interests of banks. On the other hand, interest in bills of exchange increased, often issued when credit agreements were concluded that involve large amounts, usually above PLN 100,000.
} 
http://obsil.pl/wp-content/uploads/2018/05/Opinia-z-26-lutego-2018-r.-do-projektu-MSKPC.pdf

http://www.sprawy-generalne.brpo.gov.pl/szczegoly.php?pismo=957722\&sygnatura= V.510.5.2017

https://legislacja.rcl.gov.pl/docs//2/12305652/12474240/12474241/dokument318935.pdf

https://radalegislacyjna.gov.pl/dokumenty/opinia-z-8-lutego-2018-r-o-projekcie-ustawy-ozmianie-ustawy-kodeks-postepowania-cywilnego

Janas, S. (2013). Bankowe tytuty egzekucyjne (wybrane zagadnienia procesowe). „Polski Proces Cywilny" nr 3.

Janiak, A. (2003). Przywileje bankowe w prawie polskim. Kraków: Wyd. Zakamycze.

Janus, P. (2017). Konstytucyjność bankowego tytułu egzekucyjnego. Glosa do wyroku TK z dn. 14.04.2015 r. (P45/12). „Monitor Prawa Bankowego” nr 11.

Jasiecki, A. (2017). Postępowanie nakazowe z powództwa banku (art. 485 \& 3 KPC) - do uchylenia czy zmiany (wybrane problemy)?. „Monitor Prawniczy” nr 17.

Kaszubowski, R., Tupaj-Cholewa, A. (2010). Prawo bankowe. Warszawa: Wyd. Wolters Kluwer Polska.

Kryński, B. (2000). Czy Narodowy Bank Polski ma prawo wydawać bankowe tytuty egzekucyjne?. „Prawo Bankowe” nr 5.

Kryński, E. (2007). Bankowy tytuł egzekucyjny w orzecznictwie Trybunatu Konstytucyjnego i Sądu Najwyższego. „Prawo Bankowe” nr 5.

Kurzępa-Dedo, K., Kurzępa, E. (2016). Analiza instytucjonalna ustawy z 19.04.2013r. o zmianie ustawy - Prawo bankowe oraz ustawy o funduszach inwestycyjnych. „Przeglad Prawa Publicznego" nr 10.

Marciniak, A., Piasecki, K., red. (2016). Kodeks postępowania cywilnego. T. II. Art. 367-729. Warszawa: Wyd. C.H. Beck, system Informacji Prawnej „Legalis”.

Marszałkowska-Krześ, E., red. (2017). Kodeks postępowania cywilnego. Komentarz, Warszawa: Wyd. C.H. Beck, System Informacji Prawnej „Legalis”.

Morawski, W. (1996). Bankowość prywatna w II Rzeczypospolitej. Warszawa: Wyd. SGH.

Piasecki, K., red. (2015). Kodeks postepowania cywilnego. T. III. Komentarz. Art. 730-1088. Wyd. 6. Warszawa: Wyd. C.H. Beck, System Informacji Prawnej „Legalis”.

Pietrzkowski, H. (2009) [w:] Ereciński, T., Komentarz KPC. T. 4. Warszawa: Wyd. Wolters Kluwer Polska.

Pismo Rzecznika Praw Obywatelskich Adama Bodnara do Prezesa Związku Banków Polskich Krzysztofa Pietraszkiewicza, sygn. V.7220.64.2017.EG, https://www.rpo.gov.pl/sites/default/ files/WG\%20roczne\%20do\%20ZBP\%202017\%20r..pdf.

Postanowienie Trybunału Konstytucyjnego z 29 listopada 2005 r. P. 10/2005, LexPolonica nr 411562.

Rozporządzenia Ministra Sprawiedliwości z dnia 22 października 2015 roku w sprawie opłat za czynności adwokackie (Dz.U. z 2015 r., poz. 1800 ze zm.).

Rozporządzenie Prezydenta Rzeczypospolitej Polskiej z dnia 20 stycznia 1924 r. w przedmiocie ustanowienia statutu dla banku emisyjnego (tekst jedn. Dz.U. z 1939 r., nr 46, poz. 296).

Rozporządzenie Prezydenta Rzeczypospolitej Polskiej z dnia 21 października 1932 r. o wykonywaniu egzekucji z nieruchomości przez Państwowy Bank Rolny (Dz.U. nr 91, poz. 769). 
Sikorski, G. (1997). Komentarz do ustawy Prawo bankowe. Sopot: Wyd. Stowarzyszenia Komorników Sądowych „CURRENDA”.

Sura, R. (2016). Glosa do wyroku TK z dnia 14 kwietnia 2015 r., P 45/12. Koniec z reliktem przeszłości. Bankowy tytuł egzekucyjny niezgodny z konstytucja, GSP-Prz.Orz. nr 1.

Szpunar, A. (1995). Glosa do wyroku SN z dnia 15 lutego 1995 r. II CRN 165/94, PiP nr 9.

Turski, P. (2017). BTE - o swoistości stosowania w nowych realiach prawnych. „,Monitor Prawa Bankowego" nr 6.

Uchwała Sądu Najwyższego z dnia 17 kwietnia 1985 r. III CZP 14/85, OSNC 1985, nr 12, poz. 192.

Uchwała Sądu Najwyższego z dnia 19 marca 2010 r. III CZP 6/10, OSNC 2010, nr 9, poz. 120. Uchwała Sądu Najwyższego z dnia 20 lipca 1999 r., III CZP 14/99, OSP 2000, nr 3, poz. 41.

Uchwała Sądu Najwyższego z dnia 24 października 2001 r. III CZP 53/01, „Wokanda” 2002, nr 3.

Uchwała Sądu Najwyższego z dnia 5 lipca 1974 r. III CZP 25/74, OSNC 1975, nr 1, poz. 2.

Ustawa z dnia 10 września 2015 roku o zmianie niektórych ustaw w związku ze wspieraniem polubownych metod rozwiązywania sporów (Dz.U. z 2015 r., poz. 1595).

Ustawa z dnia 12 kwietnia 2013 r. o zmianie ustawy - Prawo bankowe oraz ustawy o funduszach inwestycyjnych (Dz.U. z 2013 r., poz. 777).

Ustawa z dnia 17 listopada 1964 r. - Kodeks postępowania cywilnego (tekst jedn. Dz.U. z 2018 r., poz. 1360 ze zm.)

Ustawa z dnia 24 marca 1933 r. o ułatwieniach dla instytucji kredytowych, przyznających dłużnikom ulgi w zakresie wierzytelności rolniczych (Dz.U. z 1934 r., nr 109, poz. 973).

Ustawa z dnia 25 września 2015 r. o zmianie ustawy - Prawo bankowe oraz niektórych innych ustaw (Dz.U. 2015, poz. 1854).

Ustawa z dnia 26 czerwca 2009 r. o zmianie ustawy o księgach wieczystych i hipotece oraz niektórych innych ustaw (Dz.U. nr 131, poz. 1075).

Ustawa z dnia 28 lipca 2005 r. o kosztach sądowych w sprawach cywilnych (tekst jedn. Dz.U. 2019 r., poz. 785).

Ustawa z dnia 29 sierpnia 1997 r. - Prawo bankowe (tekst jedn. Dz.U. z 2018 r., poz. 2187 ze zm.).

Ustawa z dnia 5 listopada 2009 r. o spółdzielczych kasach oszczędnościowo-kredytowych (tekst jedn. Dz.U. z 2018 r., poz. 2386).

Wyrok Sądu Najwyższego z dnia 15 lutego 1995 r. II CRN 165/94, OSG 1996, nr 2, poz. 14.

Wyrok Trybunału Konstytucyjnego z dnia 14 kwietnia 2015 r., P 45/12, OTK-A 2015/4/46.

Wyrok Trybunału Konstytucyjnego z dnia 15 marca 2011 r. (P 7/09), Dz.U. nr 72, poz. 388.

Wyrok Trybunału Konstytucyjnego z dnia 16 maja 1995 r. K. 12/93, LexPolonica nr 313979, OTK 1995, nr 1, poz. 14.

Wyrok Trybunału Konstytucyjnego z dnia 26 stycznia 2005 r., P. 10/2004, LexPolonica nr 373239, OTK-A 2005, nr 1, poz. 7.

Zapadka, P., Mikos-Sitek, A. (2009). Polskie prawo bankowe: wybrane zagadnienia. Warszawa: Wyd. Wolters Kluwer Polska.

Zedler, F. (1995). Postęowanie zabezpieczajace i egzekucyjne. Komentarz. Toruń: Wydawnictwo TNOiK „Dom Organizatora”. 
Zieliński A., red. (2012). Kodeks postępowania cywilnego. Komentarz. 6 wydanie. Warszawa: Wyd. C.H. Beck.

DOI: $10.7862 /$ rz.2020.hss.19

The text was submitted to the editorial office: October 2019.

The text was accepted for publication: June 2020. 